Provided for non-commercial research and education use. Not for reproduction, distribution or commercial use.

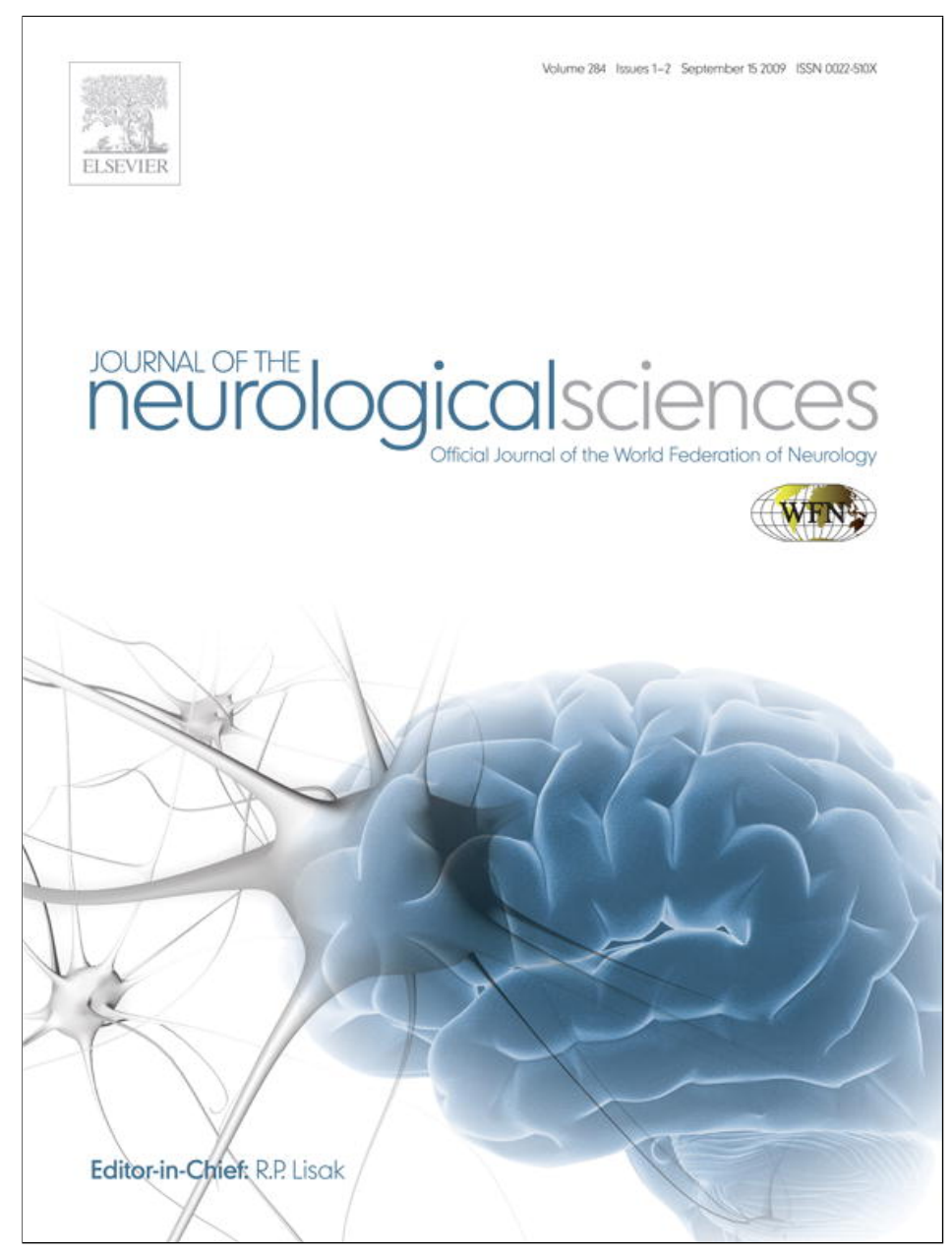

This article appeared in a journal published by Elsevier. The attached copy is furnished to the author for internal non-commercial research and education use, including for instruction at the authors institution and sharing with colleagues.

Other uses, including reproduction and distribution, or selling or licensing copies, or posting to personal, institutional or third party websites are prohibited.

In most cases authors are permitted to post their version of the article (e.g. in Word or Tex form) to their personal website or institutional repository. Authors requiring further information regarding Elsevier's archiving and manuscript policies are encouraged to visit:

http://www.elsevier.com/copyright 


\title{
Down-regulation of cerebellar $5-\mathrm{HT}_{2 \mathrm{C}}$ receptors in pilocarpine-induced epilepsy in rats: Therapeutic role of Bacopa monnieri extract
}

\author{
Amee Krishnakumar, Pretty Mary Abraham, Jes Paul, C.S. Paulose* \\ Molecular Neurobiology and Cell Biology Unit, Centre for Neuroscience, Department of Biotechnology, Cochin University of Science and Technology, Cochin-682 022, Kerala, India
}

\section{A R T I C L E I N F O}

\section{Article history:}

Received 19 August 2008

Received in revised form 8 March 2009

Accepted 20 April 2009

Available online 13 May 2009

\section{Keywords:}

Epilepsy

$5-\mathrm{HT}_{2 \mathrm{C}}$ receptor

Cerebellum

Bacopa monnieri

Motor dysfunction

CT value

Log RQ value

\begin{abstract}
A B S T R A C T
Epilepsy is a syndrome of episodic brain dysfunction characterized by recurrent unpredictable, spontaneous seizures. Cerebellar dysfunction is a recognized complication of temporal lobe epilepsy and it is associated with seizure generation, motor deficits and memory impairment. Serotonin is known to exert a modulatory action on cerebellar function through $5 \mathrm{HT}_{2 \mathrm{C}}$ receptors. $5-\mathrm{HT}_{2 \mathrm{C}}$ receptors are novel targets for developing anticonvulsant drugs. In the present study, we investigated the changes in the $5-\mathrm{HT}_{2 \mathrm{C}}$ receptors binding and gene expression in the cerebellum of control, epileptic and Bacopa monnieri treated epileptic rats. There was a significant down regulation of the 5-HT content $(p<0.001), 5-\mathrm{HT}_{2 \mathrm{C}}$ gene expression $(p<0.001)$ and $5-\mathrm{HT}_{2 \mathrm{C}}$ receptor binding $(p<0.001)$ with an increased affinity $(p<0.001)$. Carbamazepine and B. monnieri treatments to epileptic rats reversed the down regulated $5-\mathrm{HT}$ content $(p<0.01), 5-\mathrm{HT}_{2 \mathrm{C}}$ receptor binding $(p<0.001)$ and gene expression $(p<0.01)$ to near control level. Also, the Rotarod test confirms the motor dysfunction and recovery by $B$. monnieri treatment. These data suggest the neuroprotective role of $B$. monnieri through the upregulation of $5-\mathrm{HT}_{2 \mathrm{C}}$ receptor in epileptic rats. This has clinical significance in the management of epilepsy. () 2009 Elsevier B.V. All rights reserved.
\end{abstract}

\section{Introduction}

Serotonin plays an important regulatory role in epileptic mechanisms; as demonstrated from studies in both animal models of epilepsy and humans. Reciprocal interactions between the motor system and the serotonergic modulatory system are well documented [1]. In the genetically epilepsy-prone rat model of generalized epilepsy, a decrease is found in brain concentration of serotonin [2]. 5- $\mathrm{HT}_{2 \mathrm{C}}$ receptors are involved in a diversity of physiological functions such as the control of nociception, motor behaviour, endocrine secretion, thermoregulation, modulation of appetite and the control of exchanges between the central nervous system and the cerebrospinal fluid $[3,4]$. There has been increasing evidence that serotonergic neurotransmission modulates a wide variety of experimentally induced seizures. Generally, agents that elevate extracellular serotonin (5-HT) levels, such as 5-hydroxytryptophan and serotonin reuptake blockers, inhibit both focal and generalized seizures. Conversely, depletion of brain 5-HT lowers the threshold to audiogenically, chemically and electrically evoked convulsions [5]. The cerebellar cortex, like all other motor structures, receives serotonergic innervations in the form of a plexus of fine varicose fibers. [6]. Electrophysiologists have reported that serotonergic agonists can

\footnotetext{
* Corresponding author. Molecular Neurobiology and Cell Biology Unit, Centre for Neuroscience, Department of Biotechnology, Cochin University of Science and Technology, Cochin-682022, Kerala, India. Tel./fax: +91 484 2575588, 2576267.

E-mail address: cspaulose@cusat.ac.in (C.S. Paulose).
}

affect directly the firing of cerebellar neurons [7] and are able to modulate the effect of excitatory amino acids.

The cerebellum is known to play an important part in sensorimotor processing. Its major functions range from motor and sensory timing [8] to calibration of movements and reflexes $[9,10]$. Lesions in the cerebellum typically cause hypotonia, dysmetria and dyscoordination [11]. Cerebellar atrophy is a recognized complication of temporal lobe epilepsy. The cerebellar system is also implicated in memory impairment which has been mainly ascribed to hippocampal damage [12] observed during epilepsy. The neurons of the deep cerebellar nuclei comprise the main output stage of the cerebellum [13]. Epileptic patients have shown glutamate mediated neuronal damage in the cerebellum, associated with loss of Purkinje cells that provide the sole output pathway of the cerebellar cortex. Earlier studies have also established that rhythmic output from the cerebellum contributes to the maintenance of generalized seizures [14].

The potential for antiepileptic drugs to negatively impact cognitive abilities is of significant concern because they are the major therapeutic modality for control of seizures. An increased risk for cognitive deficits has been noted in patients with temporal lobe seizures. Moreover, many of the anticonvulsant drugs presently used for treating epilepsy cannot prevent neurodegeneration but rather contribute towards these cognitive deficits $[15,16]$. The available antiepileptic drugs are not curative since they mostly treat the symptoms of the disease and render little help to alleviate its cause. This has instilled a renewed interest in traditionally used herbal drugs and formulations, which are safe in prolonged usage for the management of epilepsy. 
Bacopa monnieri is well known for its neuropharmacological effects. It is currently recognized as being effective in the treatment of mental illness and epilepsy [17]. Treatments with B. monnieri extract [18] have enhanced learning ability. Cognition-facilitating effect was due to two active saponins, bacosides A and B present in the ethanol extract [19]. These active principles, apart from facilitating learning and memory in normal rats, inhibited the amnesic effects of scopolamine, electroshock and immobilization stress [20]. Crude plant extract or bacosides have also shown anxiolytic effects, antidepressant activity, anticonvulsive action and antioxidant activity [21]. In vitro studies using B. monnieri have been found to inhibit free radical formation and DNA damage in a dose dependent manner [17]. In our previous studies, we reported that the down regulated expression of the mGluR8 in cerebellum of epileptic rats was reversed after $B$. monnieri treatment [22]. But so far there are very few studies reporting the role of $B$. monnieri treatment on the functional regulation of $5-\mathrm{HT}_{2 \mathrm{C}}$ receptors. In this study, we investigated the anti-epileptic effect of extract of $B$. monnieri on the serotonergic receptor binding, gene expression in cerebellum and motor function by Rotarod Test in epileptic rats.

\section{Methods}

\subsection{Biochemicals and their sources}

Biochemicals used in the present study were purchased from Sigma Chemical Co., St. Louis, USA. All other reagents were of analytical grade purchased locally. Tri-reagent kit was purchased from MRC, USA. Real-time PCR Taqman probe assays on demand were purchased from Applied Biosystems, Foster City, CA, USA.

\subsection{Animals}

Adult male Wistar rats were purchased from Amrita Institute of Medical Sciences, Cochin and used for all experiments. They were housed in separate cages under $12 \mathrm{~h}$ light and $12 \mathrm{~h}$ dark periods and were maintained on standard food pellets and water ad libitum. The adult rats used for epilepsy experiment were sacrificed by decapitation after 15 days' treatment with $B$. monnieri extract. The cerebellum was dissected out quickly over ice according to the procedure of Glowinski and Iversen [23]. All animal care and procedures were in accordance with Institutional and National Institute of Health guidelines.

\subsection{Plant material and preparation of extract}

Specimens of B. monnieri (L.) Pennel were collected from Cochin University area and were taxonomically identified and authenticated by Mr. K. P. Joseph, Head, Dept. of Botany (retd.), St. Peter's College, Kollenchery and voucher specimens was deposited at a herbarium (No: MNCB3) of Centre for Neuroscience, Cochin University of Science and Technology, Cochin, Kerala, India. Fresh, whole B. monnieri plant were collected and washed. Leaves, roots and stems of $B$. monnieri plant were cut into small pieces and dried in shade. $100 \mathrm{~g}$ fresh plant dried in shade yielded approximately $15 \mathrm{~g}$ powder. Dry B. monnieri powder was ground to fine paste and made into a suspension. This suspension was administered at a dosage of $1.5-1.8 \mathrm{ml}$ to experimental rats weighing $250 \mathrm{~g}-300 \mathrm{~g}$ body weight by gavation per day for 15 days. B. monnieri suspension was extracted at required concentration (300 $\mathrm{mg}$ fresh plant/ $\mathrm{kg}$ body weight) with saline and used for the treatment of epileptic rats in the present study.

\subsection{Induction of epilepsy in adult rats}

Animal groups: Experimental rats were divided into five groups: 1) Control (C) 2) Epileptic (E) 3) Epileptic rats treated with B. monnieri $(\mathrm{E}+\mathrm{B})(4)$ Control rats treated with B. monnieri $(\mathrm{C}+\mathrm{B})$ and $(5)$
Epileptic rats treated with carbamazepine $(\mathrm{E}+\mathrm{C})$. B. monnieri treated rats were given extract of $B$. monnieri orally by gavage in the dosage $300 \mathrm{mg}$ fresh plant/kg body/day for 15 days. Carbamazepine-a standard drug used for the treatment of epilepsy was given orally in the dosage $150 \mathrm{mg} / \mathrm{kg}$ body/day for 15 days. A total of 77 rats were used in for quantification of 5- $\mathrm{HT}, 5-\mathrm{HT}_{2 \mathrm{C}}$ receptor binding, 5- $\mathrm{HT}_{2 \mathrm{C}}$ gene expression and rotarod test. Control $(n=15)$, epileptic $(n=15)$ and B. monnieri treated epileptic rats $(n=17), B$. monnieri treated control rats $(n=15)$ and carbamazepine treated epileptic rats $(n=15)$.

Experimental protocol: Adult male Wistar rats, weighing 250-300 g, were housed for 1 to 2 weeks before experiments were performed. Epilepsy was induced by injecting rats with pilocarpine $(350 \mathrm{mg} / \mathrm{kg}$ i.p.), preceded by $30 \mathrm{~min}$ with atropine $(1 \mathrm{mg} / \mathrm{kg}$ i.p.) to reduce peripheral pilocarpine effects. Within 20 to $40 \mathrm{~min}$ after the pilocarpine injection, essentially all the animals developed status epilepticus (SE). Control animals were given saline injection. Behavioural observation continued for $5 \mathrm{~h}$ after pilocarpine injection. SE was allowed to continue for $1 \mathrm{~h}$ and then control and experimental animals were treated with diazepam ( $4 \mathrm{mg} / \mathrm{kg}$ i.p.). Animals were observed for the next 3 weeks. 24 days after pilocarpine treatment, the rats were continuously video monitored for $72 \mathrm{~h}$. The behaviour and seizures were captured with a CCD camera and a Pinnacle PCTV capturing software card. One trained technician, blind to all experimental conditions, viewed all videos. Seizure activity was rated according to Racine Scale [24]. Seizures were assessed by viewing behavioural postures (i.e. lordosis, straight tail, jumping/running, forelimb clonus and/or rearing) during observation of the videos. Experimental rats which showed continuous recurrent seizures were used for the further experiments.

\subsection{Quantification of 5-HT}

5-HT content in the cerebellum was assayed according to the modified procedure of Paulose et al. [25] in high performance liquid chromatography (HPLC) with electrochemical detector (ECD) (Waters, USA) fitted with CLC-ODS reverse phase column of $5 \mu \mathrm{m}$ particle size. The tissue was homogenised in $0.4 \mathrm{~N}$ perchloric acid. The homogenate was then centrifuged at $5000 \times \mathrm{g}$ for $10 \mathrm{~min}$ at $4{ }^{\circ} \mathrm{C}$ in a Sigma $3 \mathrm{~K} 30$ refrigerated centrifuge and the clear supernatant was filtered through $0.22 \mu \mathrm{m}$ HPLC grade filters and used for HPLC analysis. The mobile phase consisted of $50 \mathrm{mM}$ sodium phosphate dibasic, $0.03 \mathrm{M}$ citric acid, $0.1 \mathrm{mM}$ EDTA, $0.6 \mathrm{mM}$ sodium octyl sulfonate, 15\% methanol. The $\mathrm{pH}$ was adjusted to 3.25 with orthophosphoric acid, filtered through $0.22 \mu \mathrm{m}$ filter (Millipore) and degassed. A Waters (model 515, Milford, USA) pump was used to deliver the solvent at a rate of $1 \mathrm{ml} / \mathrm{min}$. 5-HT was identified by amperometric detection using an electrochemical detector (Waters, model 2465) with a reduction potential of $+0.80 \mathrm{~V}$. Twenty microlitre aliquots of the acidified supernatant were injected into the system for detection. The peaks were identified by relative retention times compared with external standards and quantitatively estimated using an integrator (Empower software) interfaced with the detector. Data from different brain regions of the experimental and control rats were statistically analysed and tabulated.

\subsection{Protein determination}

Protein was measured by the method of Lowry et al. [26] using bovine serum albumin as standard. The intensity of the purple blue colour formed was proportional to the amount of protein which was read in a spectrophotometer at $660 \mathrm{~nm}$.

\section{7. $5-H T_{2 C}$ receptor binding studies using $\left[{ }^{3} \mathrm{H}\right]$ mesulergine}

5- $\mathrm{HT}_{2 \mathrm{C}}$ receptor assay was done using $\left[{ }^{3} \mathrm{H}\right]$ mesulergine in the synaptic membrane preparations as previously described by Herrick- 
Davis et al. [27]. Crude synaptic membrane preparation was suspended in $50 \mathrm{mM}$ Tris-HCL buffer (pH 7.4) and used for assay. In the saturation binding experiments, assays were done using different concentrations i.e., $0.05 \mathrm{nM}-3 \mathrm{nM}$ of $\left[{ }^{3} \mathrm{H}\right]$ mesulergine was incubated with and without excess of unlabelled 5-HT $(100 \mu \mathrm{M})$ and in competition binding experiments the incubation mixture contained $0.5 \mathrm{nM}$ of $\left[{ }^{3} \mathrm{H}\right]$ mesulergine with and without 5-HT at a concentration ranging from $10^{-12}$ to $10^{-4} \mathrm{M}$.

Tubes were incubated at $25{ }^{\circ} \mathrm{C}$ for $60 \mathrm{~min}$. and filtered rapidly through GF/C filters (Whatman). The filters were washed quickly by three successive washing with $5.0 \mathrm{ml}$ of ice cold $50 \mathrm{mM}$ Tris buffer, $\mathrm{pH}$ 7.4. Bound radioactivity was counted with cocktail-T in a Wallac 1409 liquid scintillation counter.

\subsection{Receptor data analysis}

The data were analysed according to Scatchard [28]. The specific binding was determined by subtracting non-specific binding from the total. The binding parameters, maximal binding $\left(B_{\max }\right)$ and equilibrium dissociation constant $\left(K_{\mathrm{d}}\right)$, were derived by linear regression analysis by plotting the specific binding of the radioligand on $x$-axis and bound/free on $y$-axis. The maximal binding is a measure of the total number of receptors present in the tissue and the equilibrium dissociation constant is the measure of the affinity of the receptors for the radioligand. $K_{\mathrm{d}}$ is inversely related to receptor affinity. The displacement data were analysed by nonlinear regression using GraphPad Prism software, GraphPad Inc., USA. The concentration of the competing drug that competes for half the specific binding was defined as $\mathrm{EC}_{50}$ which is same as $\mathrm{IC}_{50}$ [29]. The affinity of the receptor for the competing drug is designated as $K_{i}$ and is defined as the concentration of the competing ligand that will bind to half the binding sites at equilibrium in the absence of radioligand or other competitors [30].

The data of the competitive binding assay are represented graphically with the negative log of concentration of the competing drug on the $x$-axis and percentage of the radioligand bound on the $y$ axis. The Hill slope was used to indicate a one or two sited model of curve-fitting.

\subsection{Real-Time PCR assay}

RNA was isolated from the cerebellum using Tri reagent. Total cDNA synthesis was performed using ABI PRISM cDNA Archive kit Real-Time PCR assays were performed in 96-well plates in ABI 7300 Real-Time PCR instrument (Applied Biosystems). PCR analyses were conducted with gene-specific primers and fluorescently labeled Taq 5$\mathrm{HT}_{2 \mathrm{C}}$ (designed by Applied Biosystems). Endogenous control ( $\beta$-actin) was labeled with a report dye (VIC). All reagents were purchased from Applied Biosystems. The thermocycling profile conditions were as follows:

$$
\begin{aligned}
& 50^{\circ} \mathrm{C} \text { - } 2 \text { minutes - Activation, } 95^{\circ} \mathrm{C}-10 \text { minutes } \\
& \text { - Initial Denaturation, } 95^{\circ} \mathrm{C}-15 \text { seconds } \\
& \text { - Denaturation } 40 \text { cycles, } 50^{\circ} \mathrm{C} \text { - } 30 \text { seconds } \\
& \text { - Annealing, } 60^{\circ} \mathrm{C}-1 \text { minute }- \text { Final Extension }
\end{aligned}
$$

The $\Delta \Delta C T$ method of relative quantification was used to determine the fold change in expression. This was done by first normalizing the resulting threshold cycle $(\mathrm{CT})$ values of the target mRNAs to the CT values of the internal control $\beta$-actin in the same samples $(\Delta \mathrm{CT}=\mathrm{CT}$ Target $-\mathrm{CT} \beta$-actin). It was further normalized with the control $(\Delta \Delta \mathrm{CT}=\Delta \mathrm{CT}-\mathrm{CT}$ Control). The fold change in expression was then obtained $\left(2^{-\Delta \Delta C T}\right)$.

\subsection{Rotarod test}

Rotarod has been used to evaluate motor coordination by testing the ability of rats to remain on revolving rod [31]. The apparatus has a horizontal rough metal rod of $3 \mathrm{~cm}$ diameter attached to a motor with variable speed. This $70 \mathrm{~cm}$ long rod was divided into four sections by wooden partitions. The rod was placed at a height of $50 \mathrm{~cm}$ to discourage the animals to jump from the rotating rod. The rate of rotation was adjusted to allow the normal rats to stay on it for $5 \mathrm{~min}$. Each rat was given five trials before the actual reading was taken. The readings were taken at 10,15 and $25 \mathrm{rpm}$ after 15 days of treatment in all groups of rats.

\subsection{Statistics}

Statistical evaluations were done by ANOVA followed by StudentsNewman-Keul Test using InStat (Ver.2.04a) computer programme. Linear regression Scatchard plots were made using SIGMA PLOT (Ver 2.03). The significance level was expressed taking $p<0.05$ as the threshold value. $p$ value $<0.05$ is considered as significant, $p$ value $<0.01$ as very significant and $p<0.001$ as extremely significant.

\section{Results}

\subsection{5-HT content in the cerebellum of control and experimental rats}

5-HT content in the cerebellum was significantly decreased $(p<0.001)$ in the epileptic rats. Both $(p<0.01)$ carbamazepine treatment and $B$. monnieri treatment significantly reversed the alterations in the cerebellar 5-HT content to near control. There was no significant alteration in the 5-HT content of B. monnieri treated control rats compared to control (Table 1).

\section{2. $\left[{ }^{3} \mathrm{H}\right]$ Mesulergine binding against mesulergine in the cerebellum of control and experimental rats}

Scatchard analysis showed that the $B_{\max }$ decreased significantly $(p<0.001)$ in the cerebellum of epileptic rats with a significant increase $(p<0.01)$ in the affinity. Both carbamazepine treatment and B. monnieri treatment significantly reversed the $B_{\max }(p<0.001)$ and $K_{\mathrm{d}}(p<0.01)$ to near control compared to epileptic group (Table 2$)$. There was no significant alteration in the $5-\mathrm{HT}_{2 \mathrm{C}}$ receptor of B. monnieri treated control rats compared to control. In the displacement analysis, the competitive curve fitted to a one-site model in all groups with Hill slope values near to unity. The $\log \left(\mathrm{EC}_{50}\right)$ and $K_{i}$ showed a decrease in the epileptic group. Treatment with $B$. monnieri reversed the $K_{i}$ and $\mathrm{EC}_{50}$ near to control level compared to the epileptic group (Table 3$)$. There was no alteration in the $\log \left(\mathrm{EC}_{50}\right)$ and $K_{i}$ of $B$. monnieri treated control rats compared to control.

Table 1

5-HT content in the cerebellum of control and experimental rats.

\begin{tabular}{ll}
\hline Experimental group & 5-HT (nmol/g wet wt.) \\
\hline Control & $2.76 \pm 0.12$ \\
Epileptic & $1.52 \pm 0.18^{@ @ @ ~}$ \\
Control + Bacopa monnieri & $2.81 \pm 0.14$ \\
Epileptic + Bacopa monnieri & $2.32 \pm 0.05^{* *}$ \\
Epileptic + Carbamazepine & $2.10 \pm 0.09^{* *}$ \\
\hline
\end{tabular}

Values are Mean \pm SEM of 4-6 separate experiments ( $n=5-6$ rats per group). ANOVA followed by Students-Newman-Keuls' Test.

@@@ $p<0.001$ when compared to Control rats. $* * p<0.01$ when compared to Epileptic rats. 
Table 2

Scatchard analysis of $\left[{ }^{3} \mathrm{H}\right]$ mesulergine binding against mesulergine in cerebellum of control and experimental rats.

\begin{tabular}{lll}
\hline Experimental group & $B_{\max }($ fmoles/mg protein $)$ & $K_{\mathrm{d}}(\mathrm{nM})$ \\
\hline Control & $288 \pm 10$ & $0.68 \pm 0.04$ \\
Epileptic & $95 \pm 4^{@ @ @ ~}$ & $0.41 \pm 0.08^{@ @ ~}$ \\
Control + Bacopa monnieri & $299 \pm 60$ & $0.70 \pm 0.05$ \\
Epileptic + Bacopa monnieri & $207.33 \pm 18.70^{* * *}$ & $0.69 \pm 0.06^{* *}$ \\
Epileptic + Carbamazepine & $254.00 \pm 15.52^{* * *}$ & $0.79 \pm 0.31^{* *}$ \\
\hline
\end{tabular}

Values are mean \pm SEM of 4-6 separate experiments; $n=5-6$ in each group. ANOVA followed by Students-Newman-Keuls' Test.

$@ @ @<0.001,{ }^{@ @ ~} p<0.001$ when compared to Control group.

$* * * p<0.001,{ }^{* *} p<0.001$ when compared to Epileptic group.

3.3. Real-Time-PCR analysis of $5-H T_{2 C}$ receptor expression in the cerebellum of control and experimental rats

Real-Time-PCR analysis showed that the 5- $\mathrm{HT}_{2 \mathrm{C}}$ receptor mRNA significantly decreased $(p<0.001)$ in epileptic condition when compared to control and it reversed to near control level in carbamazepine treated and B. monnieri $(p<0.01)$ treated epileptic rats (Fig. 1). There was no significant alteration in the $5-\mathrm{HT}_{2 \mathrm{C}}$ receptor mRNA expression of $B$. monnieri treated control rats compared to control.

\subsection{Rotarod experiment in the control and experimental rats}

Rotarod experiment at $10(p<0.001), 15(p<0.001)$ and 25 $(p<0.01)$ revolutions per minute $(\mathrm{rpm})$ showed a significant decrease in the retention time on the rotating rod in epileptic group compared to control. B. monnieri treatment to epileptic rats significantly reversed the retention time near to control at $10(p<0.01), 15(p<0.01)$ and 25 $(p<0.05) \mathrm{rpm}$. Carbamazepine treatment to epileptic rats significantly reversed the retention time near to control at $10(p<0.01), 15$ $(p<0.001)$ and $25(p<0.05)$ rpm (Table 4$)$.

\section{Discussion}

In our earlier studies, we reported the therapeutic action of B. monnieri on glutamate receptors especially in the cerebellum and hippocampus of pilocarpine induced epilepsy in rats $[21,22]$. In the present study, we have demonstrated the therapeutic role of B. monnieri in epileptic motor dysfunction through its effect on 5$\mathrm{HT}_{2 \mathrm{C}}$ receptor gene expression and binding in cerebellum. Experimental evidence indicate the involvement of the cerebellum in variety of human mental activities including language, attention, cognitive affective syndromes [11], fear and anxiety caused by threats of pain [32] and motor relearning [33]. The cerebellar vermis integrates and processes the inputs from the vestibular, visual and proprioceptive systems to coordinate muscle timing as a result of which the centre of gravity stays within the limits of stable upright standing [34]. 5- $\mathrm{HT}_{2 \mathrm{C}}$ receptors exist in the rat cerebellum and they participate in the

Table 3

Binding parameters of $\left[{ }^{3} \mathrm{H}\right]$ mesulergine against mesulergine in cerebellum of control and experimental rats.

\begin{tabular}{lllll}
\hline Experimental status & Best fit model & $\left(\right.$ Log EC $\left._{50}\right)$ & $K_{i}$ & Hill slope \\
\hline Control & One-site & -7.434 & $2.01 \times 10^{-8}$ & 0.95 \\
Epileptic & One-site & -7.913 & $6.66 \times 10^{-9}$ & 0.95 \\
Control + Bacopa monnieri & One-site & -7.354 & $2.41 \times 10^{-8}$ & 0.93 \\
Epileptic + Bacopa monnieri & One-site & -7.704 & $1.07 \times 10^{-8}$ & 0.96 \\
Epileptic + Carbamazepine & One-site & -7.472 & $1.84 \times 10^{-8}$ & 0.96 \\
\hline
\end{tabular}

Values are mean \pm SEM of 4-6 separate experiments.

Data were fitted with iteratative non linear regression software (Prism, Graph Pad, San Diego, CA). $K_{i}$-the affinity of the receptor for competing for the drug. E50 is the concentration for the competitor that competes for half specific bind.

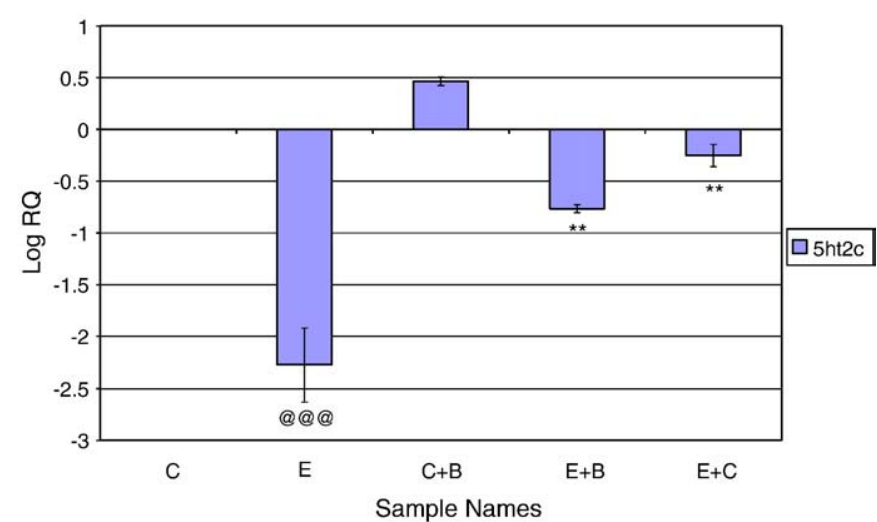

Values are Mean \pm SEM of 4-6 separate experiments ( $n=5-6$ rats per group) ANOVA

followed by Students-Newman-Keuls' Test.

@@@ $p<0.001$ when compared to Control group

** $p<0.01$ when compared to Epileptic group

Fig. 1. Real-Time PCR amplification of 5- $\mathrm{HT}_{2 \mathrm{C}}$ receptor mRNA from cerebellum of control and experimental rats. Relative Quantification values and standard deviations are shown in the table. The relative ratios of mRNA levels were calculated using the $\Delta \Delta C T$ method normalized with $\beta$-actin CT value as the internal control and Control CT value as the calibrator. C-Control, E-Epilepsy, C + B-Control + Bacopa monnieri treated, E + BEpileptic + Bacopa monnieri treated, E + C-Epileptic + Carbamazepine treated.

processing and integration of sensory information, regulation of the monoaminergic system modulation of neuroendocrine regulation, anxiety and feeding behaviour [3]. Our investigation revealed a decrease in the 5-HT content and $5-\mathrm{HT}_{2 \mathrm{C}}$ receptor binding in the cerebellum of the epileptic rats compared to control with an increased affinity. Decreased serotonin in the brain has previously been implicated in development and spread of seizures [2]. This decreased receptor binding in the cerebellum is suggested to contribute towards a lowered threshold and a rapid progression of seizure activity in the epileptic rats. Previously, mesulergine ( 2 or $4 \mathrm{mg} / \mathrm{kg}$ ), administered prior to electroshock testing, have shown to recapitulate epileptic syndrome associated with sporadic spontaneous seizures in the 5$\mathrm{HT}_{2 \mathrm{C}}$ mutant phenotype in wild-type mice [35].

Treatment with $B$. monnieri to epileptic rats caused a reversal in the $B_{\max }$ of $5-\mathrm{HT}_{2 \mathrm{C}}$ receptors to near control level. Previous works have reported the anti-oxidant properties of $B$. monnieri in rodents and have reported to induce membrane dephosphorylation and concomitant increase in mRNA turnover and protein synthesis [21]. Moreover, B. monnieri treatment has been demonstrated to increase serotonin level [36] which renders protection against seizures [5] during epilepsy.

The Rotarod experiment demonstrated the impairment in the motor function and coordination in the epileptic rats. Epileptic rats showed lower fall off time from the rotating rod when compared to control suggesting impairment in their ability to integrate sensory input with appropriate motor commands to balance their posture and

Table 4

Rotarod performance of control and experimental rats after 15 days treatment.

\begin{tabular}{|c|c|c|c|}
\hline \multirow[t]{2}{*}{ Experimental groups } & \multicolumn{3}{|c|}{ Retention time on the rod (in seconds) } \\
\hline & $10 \mathrm{rpm}$ & $15 \mathrm{rpm}$ & $25 \mathrm{rpm}$ \\
\hline Control & $112.00 \pm 4.61$ & $109.33 \pm 6.3$ & $73.33 \pm 3.38$ \\
\hline Epileptic & $83.33 \pm 2.40^{@ @ @ ~}$ & $51.33 \pm 2.18^{@ @ @ ~}$ & $34.33 \pm 4.97^{@ @ ~}$ \\
\hline Control + Bacopa monnieri & $108.00 \pm 0.57$ & $114.66 \pm 4.70$ & $72.00 \pm 6.42$ \\
\hline Epileptic + Bacopa monnieri & $93.00 \pm 5.00^{* *}$ & $76.66 \pm 3.48^{* *}$ & $59.33 \pm 5.45^{*}$ \\
\hline Epileptic + Carbamazepine & $95.66 \pm 0.88^{* *}$ & $82.66 \pm 1.43^{* * *}$ & $55.33 \pm 3.75^{*}$ \\
\hline
\end{tabular}

Values are Mean \pm SEM of 4-6 separate experiments ( $n=5-6$ rats per group). ANOVA followed by Students-Newman-Keuls' Test.

${ }^{@ @ ~} p<0.001{ }^{@ @ ~} p<0.01$ when compared to Control rats.

$* * * p<0.001 * * p<0.01 * p<0.05$ when compared to Epileptic rats. 
at the same time adjust their limb movements on the metallic rod and is indicative of cerebellar dysfunction. Loss of coordination of motor movement, inability to judge distance and timing, incapacity to perform rapid alternating movements and hypotonia has been reported during cerebellar damage [11]. Poor limb-eye coordination in patients with cerebellar dysfunction has been earlier reported [37]. Thus perturbations of the $5-\mathrm{HT}_{2 \mathrm{C}}$ receptor system directly modulate seizure susceptibility. This study demonstrates the involvement of 5$\mathrm{HT}_{2 \mathrm{C}}$ receptor which has a modulating effect on the seizure susceptibility and associated motor defects. The administration of crude extract of $B$. monnieri to epileptic rats increased the fall off time from the rod when compared to control rats. B. monnieri not only possesses memory enhancing properties but also alleviate their stress levels which assist in lowering their time for spatial recognition [35] and helps to maintain their posture during movement on the rod. It is also reported to facilitate the acquisition, consolidation, retention and recall of learned tasks [38] and improves the speed at which visual information is processed.

To summarize, our findings suggest dysfunction of the epileptic cerebellum that is a reflection of cerebellar serotonergic abnormality. The receptor analysis and gene expression studies along with the behaviour data implicate a role for serotonin and $5-\mathrm{HT}_{2 \mathrm{C}}$ receptors in the modulation of neuronal network excitability and seizure propagation. These neurofunctional deficits are one of the key contributors to motor deficits and stress associated with epilepsy. Our results suggest that B. monnieri extract treatment reverses the $5-\mathrm{HT}_{2 \mathrm{C}}$ receptor mediated motor dysfunction in epilepsy. This will have clinical significance in the management of epilepsy.

\section{Acknowledgements}

This work was supported by research grants from the DBT, DST, ICMR, Govt. of India and KSCSTE, Govt. of Kerala to Dr. C. S. Paulose. Amee Krishnakumar thanks the ICMR, Govt. of India and Pretty Mary Abraham thanks the DST Govt. of India for Junior Research Fellowship.

\section{Appendix A. Supplementary data}

Supplementary data associated with this article can be found, in the online version, at doi:10.1016/j.jns.2009.04.032.

\section{References}

[1] Jacobs BL Fornal CA. Serotonin and motor activity. Curr Opin Neurobiol 1997· $7 \cdot 820-5$

[2] Dailey JW, Reigel CE, Mishra PK, Jobe PC. Neurobiology of seizure predisposition in the genetically epilepsy-prone rat. Epilepsy Res 1989;3:317-20.

[3] Tecott LH, Sun LM, Akana SF, Stack AM, Lowenstein DH, Dallman MF, et al. Eating disorder in mice lacking5-HT2C serotonin receptors. Nature 1995;374:542-6.

[4] Fone KCF, Austin RH, Topham IA, Kennett GA, Punhani T. Effect of chronic m-CPP on locomotion, hypophagia, plasma corticosterone and $5-\mathrm{HT}_{2 \mathrm{C}}$ receptor levels in the rat. Br J Pharmacol 1998;123:1707-15.

[5] Bagdy G, Kecskemeti V, Riba P, Jakus R. Serotonin and epilepsy. J Neurochem 2006;100:857-73.

[6] Dieudonné Stéphanne, Dumoulin Andréa. Serotonin-driven long-range inhibitory connections in the cerebellar cortex. J Neurosci 2000;20:1837-48.

[7] Cumming-Hood PA, Strahlendorf HK, Strahlendorf C. Effects of serotonin and the 5$\mathrm{HT}_{2 \mathrm{C} / 1 \mathrm{C}}$ receptor agonist. DOl on neurons of the cerebellar dentate/interpositus nuclei: possible involvement of a GABAergic interneuron. Eur J Pharmaco 1993;236:457-65.

[8] Spencer RM, Zelaznik HN, Diedrichsen J, Ivry RB. Disrupted timing of discontinuous but not continuous movements by cerebellar lesions. Science 2003;300:1437-9.
[9] Kolb TF, Lachauer S, Schoch B, Gerwig M, Timmann D, Kolb FP. Comparison of the electrically evoked leg withdrawal reflex in cerebellar patients and healthy controls. Exp Brain Res 2007;177:493-508.

[10] Oulad Ben Taib N, Manto M. Hemicerebellectomy impairs the modulation of cutaneomuscular reflexes by the motor cortex following repetitive somatosensory stimulation. Brain Res 2006;1090:110-5.

[11] Gowen E, Miall C. Behavioural aspects of cerebellar function in adults with Asperger syndrome. The Cerebellum 2005;4:1-11

[12] Morris RGM, Schenk F, Tweedie F, Jarrard LE. Ibotenate lesions of hippocampus and subiculumP: dissociating components of allocentric spatial learning. Eur J Neurosci 1990;2:1016-28.

[13] Zhang W, Linden DJ. Long-term depression at the mossy fiber in deep cerebellar nucleus synapse. J Neurosci 2006;26:6935-44.

14] Kandel A, Buzsaki G. Cerebellar neuronal activity correlates with spike and wave EEG patterns in the rat. Epilepsy Res 1993;16:1-9.

[15] Rosane BB, Helena MTB. Carbamazepine enhances discriminative memory in rat model of epilepsy. Epilepsia 2004;45:1443-7.

[16] Kwan P, Brodie MJ. Neuropsychological effects of epilepsy and antiepileptic drugs. Lancet 2001:357:216-22.

[17] Russo A, Izzo AA, Borrelli F, Renis M, Vanella A. Free radical scavenging capacity and protective effect of Bacopa monniera L. on DNA damage. Phytother Res 2003;17.

[18] Singh HK, Dhawan BN. Effect of Bacopa monniera extract on avoidance responses in rat. J Ethnopharmacol 1982;5:205-14.

[19] Singh HK, Dhawan BN. Drugs affecting learning and memory. In: Tandon PN, Bijiani V, Wadhwa S, editors. Lectures in neurobiology, vol. 1. New Delhi: Wiley Eastern; 1992. p. 189-207.

[20] Singh HK, Shanker G, Patnaik GK. Neuropharmacological and antistress effects of bacosides: a memory enhancer. Indian J Pharmacol 1996;28:47.

[21] Reas SK, Amee K, Paulose CS. Glutamate receptor gene expression and binding studies in pilocarpine induced epileptic rat: neuroprotective role of Bacopa monnieri extract. Epilep Behav 2008;12:54-60.

[22] Paulose CS, Finla C, Reas KS, Amee K. Neuroprotective role of Bacopa monnier extract in epilepsy and effect of glucose supplementation during hypoxia: glutamate receptor gene expression. Neurochem Res 2008;33:1663-71.

[23] Glowinski J, Iversen LL. Regional studies of catecholamines in the rat brain: the disposition of $\left[{ }^{3} \mathrm{H}\right]$ Norepinephrine, $\left[{ }^{3} \mathrm{H}\right]$ DOPA in various regions of the brain. J Neurochem 1966;13:655-69.

[24] Racine RJ. Modification of seizure activity by electrical stimulation. I. After discharge threshold. Electroencephalogr Clin Neurophysiol 1972;32:269-79.

[25] Paulose CS, Dakshinamurthi K, Packer S, Stephens NL. Sympathetic stimulation and hypertension in pyridoxine deficient adult rats. Hypertension 1988;11:387-91.

[26] Lowry OH, Roserbrough NJ, Farr AL, Randall RJ. Protein measurements and folin phenol reagent. J Biol Chem 1951;193:265-75.

[27] Herrick-Davis K, Grinde E, Niswender CM. Serotonin 5-HT2C receptor RNA editing alters receptor basal activity: implications for serotonergic signal transduction. J Neurochem 1999;73:1711-7.

[28] Scatchard G. The attraction of proteins for small molecules and ions. Ann of the New York Academy of Sciences 1949;51:660-72.

[29] Unnerstall Jr. Computer analysis of binding data. In: Yamura H, Nas M, Kuhar, editors. Methods in neurotransmitter receptor analysis. Raven press; 1990. p. 247-55.

[30] Cheng Y, Prusoff WH. Relationship between the inhibition constant (K1) and the concentration of inhibitor which causes 50 per cent inhibition (150) of an enzymatic reaction. Biochem Pharmacol 1973;22:3099-4008.

[31] Dunham NW, Miya TS. A note on a simple apparatus for detecting neurological deficit in rats and mice. J Am Pharmaceut Assoc 1957;XLVI(No 3) Scientific Edit.

[32] Ploghause A, Tracey I, Gati JS, Clare S, Menon RS, Matthews PM, et al. Dissociating pain from its anticipation in the human brain. Science 1999;284:1979-81.

[33] Imazumi H, Miyauchi S, Tamada T, Sasaki Y, Takino R, Futz B, et al. Human cerebellar activity reflecting an acquired internal model of a new tool. Nature 2004;03:192-5.

[34] Diener H, Dichgans J, Guschlbauer B, Bacher M, Langenbach P. Disturbances of motor preparation in basal ganglia and cerebellar disorders. Prog Brain Res 1989;80:481-8.

[35] Applegate CD, Tecott LH. Global increases in seizure susceptibility in mice lacking 5- $\mathrm{HT}_{2 \mathrm{C}}$ receptors: a behavioural analysis. Exp Neurol 1998;154:522-30.

[36] Singh HK, Dhawan BN. Neuropsychopharmacological effects of the Ayurvedic nootropic Bacopa monniera Linn (Brahmi). Indian J Pharmachol 1997:29:359-65.

[37] Van Donkelaar P, Lee RG. Interactions between the eye and hand motor systems: disruptions due to cerebellar dysfunction. J Neurophysiol 1994;72:1674-85.

[38] Roodenrys S, Booth D, Bulzomi S, Phipps A, Micallef C, Smoker J. Chronic effects of Brahmi (Bacopa monnieri) on human memory. Neuropsychopharmacology 2002;27:279-81. 